\title{
PENGARUH KNOWLEDGE MANAGEMENT DAN KOMITMEN KERJA TERHADAP KINERJA PENGURUS BADAN KESWADAYAAN MASYARAKAT (BKM) KOTA KENDARI
}

\author{
Ahmad Taufiq Soepardy \\ Program Studi Akuntansi, Fakultas Ekonomi \\ Universitas Nahdlatul Ulama Sulawesi Tenggara, Indonesia \\ e-mail: ahmadtaufiq8899@ gmail.com
}

\begin{abstract}
ABSTRAK
Penelitian ini bertujuan (1) Untuk menguji dan menjelaskan pengaruh knowlegde management dan komitmen kerja secara bersama-sama terhadap kinerja Pengurus Badan Keswadayaan Masyarakat (BKM) Kota Kendari, (2) untuk menguji dan menjelaskan pengaruh knowledge management terhadap kinerja Pengurus Badan Keswadayaan Masyarakat (BKM) Kota Kendari, (3) Untuk menguji dan menjelaskan pengaruh komitmen kerja terhadap kinerja Pengurus Badan Keswadayaan Masyarakat (BKM) Kota Kendari.Populasi dalam penelitian ini adalah sebanyak 87 orang yang merupakan pengurus BKM Kota Kendari. Teknik penarikan sampling adalah secara Probability Sampling dan analisis data menggunakan regresi linear berganda dengan bantuan program SPSS versi 21.0. Hasil penelitian menunjukkan bahwa: 1). Knowledge management dan Komitmen kerja secara bersamasama berpengaruh terhadap kinerja pengurus BKM.Hal ini menunjukan bahwa knowledge management dan komitmen kerja memiliki korelasi positif terhadap keberhasilan pengurus BKM dalam melakukan pekerjaannya. 2). Knowledge management berpengaruh terhadap kinerja pengurus BKM. Hal ini menunjukkan bahwa tinggi rendahnya kinerja pengurus BKM dipengaruhi oleh knowledge management yang diterapkan pengurus BKM se Kota Kendari. Semakin baik knowledge management yang diterapkan oleh BKM, maka akan semakin tinggi kinerja pengurus. 3). Komitmen kerja berpengaruh terhadap kinerja pengurus BKM. Hal ini menunjukkan bahwa tinggi rendahnya kinerja pengurus BKM dipengaruhi oleh komitmen kerja yang diterapkan pada BKM Kota Kendari. Semakin baik komitmen kerja yang diterapkan oleh BKM Kota Kendari, maka akan semakin tinggi kinerja pengurus BKM.
\end{abstract}

Kata Kunci : Knowledge Management, Komitmen Kerja, Kinerja Organisasi

\begin{abstract}
The research aims (1) to examine and explain the influence of knowledge management and commitment to work jointly on the performance of the Management Board of Community SelfReliance (BKM) Kendari. (2) to examine and explain the effect of knowledge management on the performance of the Management Board of Community Self-Reliance (BKM) Kendari, (3) To examine and explain the effect on the performance of work commitments Community Self-Reliance Agency Board (BKM) Kendari.The population in this study were as many 87 people who are administrators of BKM Kendari. Sampling technique isused Probability Sampling and analysis by multiple linear regression analysis using SPSS version 21.0. The results showed that: 1). Knowledge management and commitment work together to affect the performance board BKM. It shows that the knowledge management and work commitments have a positive correlation to the success of the board BKM in doing his job. 2). Knowledge management BKM affect the performance of the board. This suggests that the level of performance is affected by BKM board applied knowledge management board BKM se Kendari. The better knowledge management that is applied by the BKM, the higher the performance of the board. 3). Work commitments affect the performance of the board BKM. This
\end{abstract}


suggests that the level of performance of the board BKM is influenced by work commitments that apply to BKM Kendari. The better the work commitments adopted by BKM Kendari, the higher the performance of the board BKM.

Keywords: Knowledge Management, Work Commitment, Organizational Performance

\section{PENDAHULUAN}

Kemiskinan yang dialami oleh sebagian penduduk atau rakyat Indonesia menjadi latar belakang pelaksanaan pemberdayaan masyarakat. Berbagai sumber dapat kita lihat yang membahas tentang kemiskinan baik media elektronik maupun di media cetak. Berbagai upaya telah dilakukan oleh pemerintah untuk menurunkan kemiskinan yang dialami oleh rakyatnya. Pemerintah, melalui berbagai kajian terus mencari solusi dan alternatif penyelesaian yang tepat hingga dapat mengatasinya, baik dari aspek sosial, politik, ekonomi dan budaya.

Pembangunan pada hakikatnya merupakan suatu rangkaian upaya yang dilakukan secara terus menerus untuk mencapai suatu tingkat kehidupan masyarakat yang sejahtera lahir dan batin, untuk itu peran serta masyarakat dalam pembangunan sangat diperlukan karena merekalah objek sekaligus subjek pembangunan, sehingga berkembanglah model pembangunan partisipatif. Pembangunan partisipatif merupakan pendekatan pembangunan yang sesuai dengan hakikat otonomi daerah yang meletakkan landasan pembangunan yang tumbuh berkembang dari masyarakat, diselenggarakan secara sadar dan mandiri oleh masyarakat dan hasilnya dinikmati oleh seluruh masyarakat [1]. Melalui program-program pembangunan partisipatif tersebut diharapkan semua elemen masyarakat dapat secara bersama-sama berpartisipasi dengan cara mencurahkan pemikiran dan sumber daya yang dimiliki guna memenuhi kebutuhannya sendiri.

Program penanggulangan kemiskinan di Indonesia, melalui program yang berbentuk bantuan langsung masyarakat, merupakan bentuk paradigma program pembangunan dengan mengedepankan partisipasi masyarakat. Menurut pandangan konsep Ekonomi Keynesian paradigma pembangunan dengan mengedepankan peran pemerintah, adalah upaya menanggulangi kegagalan pasar. Peran Pemerintah menurut pengalaman empirik di berbagai negara, mengalami kegagalan yang dampaknya lebih dari kegagalan pasar. Hal ini terjadi karena adanya transaction cost yang tinggi, menurunkan efisiensi ekonomi dan menghambat pemerataan dan pertumbuhan. 
Pemberdayaan masyarakat adalah upaya untuk menciptakan dan meningkatkan kapasitas masyarakat, baik secara individu maupan berkelompok, dalam memecahkan berbagai persoalan terkait upaya peningkatan kualitas hidup, kemandirian dan kesejahteraannya. Pemberdayaan masyarakat memerlukan keterlibatan yang lebih besar dari perangkat pemerintah daerah serta berbagai pihak untuk memberikan kesempatan dan menjamin keberlanjutan berbagai hasil yang dicapai. Pelaksanaan pemberdayaan masyarakat di lapangan memerlukan adanya sinergi dari masyarakat, pemerintah daerah dan kelompok peduli (swasta, asosiasi, perguruan tinggi, media, LSM, dan lain-lain) serta kemitraan diantara ketiganya. Untuk itu agar semua pihak terlibat dalam program tersebut maka sosialisasi ke masyarakat luas perlu dilakukan secara intensif.

Penunjang pelaksanaan program tersebut selain sinergi dari masyarakat, pemerintah daerah dan kelompok peduli (swasta, asosiasi, perguruan tinggi, media, LSM, dan lainlain) serta kemitraan diantara ketiganya juga diperlukan sumber daya manusia yang memiliki komitmen untuk menjalankan program tersebut dengan penuh tanggung jawab agar semua tujuan program dapat terlaksana dan tercapai dengan baik. Hal tersebut disebabkan karena sumber daya manusia merupakan tokoh sentral dalam organisasi maupun perusahaan. Agar aktivitas manajemen berjalan dengan baik, perusahaan harus memiliki karyawan yang berpengetahuan dan berketrampilan tinggi serta usaha untuk mengelola organisasi seoptimal mungkin sehingga kinerja organisasi dapat meningkat. Organisasi yang baik adalah organisasi yang berusaha meningkatkan kemampuan sumber daya manusianya, karena hal tersebut merupakan faktor kunci untuk meningkatkan kinerja karyawan.

Badan Keswadayaan Masyarakat hadir ditengah-tengah masyarakat untuk menyinergikan semua elemen yang ada. Sebagai lembaga yang hadir ditengah-tengah masyarakat tentulah mempunyai dinamika kepengurusan yang mempengaruhi kinerja organisasi secara keseluruhan, sebagaimana data yang dirilis oleh website PNPM Mandiri Perkotaan.

\section{Tabel 1. Perkembangan BKM}

\begin{tabular}{c|l|c|c|c|c|}
\multirow{2}{*}{ Tahun } & \multirow{2}{*}{ Kota/Kab. } & \multicolumn{3}{|c|}{ TAHAP PERKEMBANGAN BKM } & \multirow{2}{*}{ Jumlah } \\
\cline { 3 - 5 } & & Awal & Berdaya & Mandiri & \\
\hline 2010 & Kota Kendari & 10 & 45 & 9 & 64 \\
\hline 2011 & Kota Kendari & 1 & 61 & 2 & 64 \\
\hline 2012 & Kota Kendari & 0 & 54 & 10 & 64 \\
\hline
\end{tabular}

Sumber Data : Website p2kp.org 
Tabel diatas menunjukkan bahwa kinerja BKM dilevel Mandiri sebagai penilaian BKM dengan berkinerja baik untuk Kota Kendari setiap tahunnya tidak mencapai 20\%, begitupula kinerja BKM dilevel Berdaya atau sedang diatara 60\% - 90\% dan Level Awal atau tidak memadai antara 0\% - 20\%. Penyebab kinerja BKM tidak signifikan di level Mandiri dikarenakan pengurus BKM yang kurang memahami dengan baik fungsi knowledge management dimana menurut Davenport dan Prusak mengartikan knowledge management sebagai eksploitasi dan pengembangan aset pengetahuan dari sebuah organisasi dengan sebuah pandangan terhadap tujuan organisasi [2]. Mengoptimalkan fungsi knowledge management dapat mengeliminir konflik kepentingan baik antar pengurus maupun organisasi dengan pihak luar.

Empat tipe interaksi antara dan diluar sebuah organisasi yang didasarkan pada perbedaan yang jelas antara tacit dan explicit knowledge yaitu sosialisasi, eksternalisasi, kombinasi, dan internalisasi [3]. Dimana dari sisi sosialisasi, BKM diperhadapkan pada banyaknya ide baik dari pengurus maupun masyarakat yang harus dikomunikasikan dan disosialisasikan sehingga tercapai dan diterimanya ide tersebut disemua kalangan. Sementara dari sisi ekternalisasi, BKM diperhadapkan pada kemampuan pengurus mendokumentasikan dan mengarsipkan segala gagasan dan ide yang disepakati. Kombinasi, bagaimana BKM melakukan transfer arsip kepada pihak-pihak yang membutuhkan. Sementara internalisasi, bagaimana BKM menjadikan segala arsip dan dokumen bisa dipahami dengan baik oleh semua pihak sehingga menjadi ide dan visi yang menyatu dengan alam pikir mereka. Dari sisi knowledge management ini, peneliti mengamati masih banyak pengurus BKM se-kota Kendari yang tidak memahami fungsi tersebut sehingga kinerja BKM tidak tercapai sesuai dengan yang diharapkan.

Sisi lain yang menjadi obyek peneliti adalah komitmen kerja pengurus BKM. Sebagai definisi yang umum,komitmen kerja diartikan sebagai sikap yang menunjukkan "loyalitas" karyawan dan merupakan proses berkelanjutan bagaimana seorang anggota organisasi mengekspresikan perhatian mereka kepada kesuksesan dan kebaikan organisasinya [4]. Komitmen mencakup juga keterlibatan kerja. Hal ini disebabkan karena antara keterlibatan kerja dengan komitmen kerja sangat erat hubungannya. Keterlibatan kerja sebagai derajat kemauan untuk menyatukan dirinya dengan pekerjaan, menginvestasikan waktu, kemampuan dan energinya untuk pekerjaan, dan menganggap pekerjaannya sebagai bagian utama dari kehidupannya [5]. 
Komitmen kerja karyawan menjadi hal yang penting bagi sebuah organisasi dalam menciptakan kelangsungan hidup sebuah organisasi apapun bentuk organisasinya. Komitmen menunjukkan hasrat karyawan sebuah perusahaan untuk tetap tinggal dan bekerja serta mengabdikan diri bagi perusahaan. Komitmen seseorang terhadap organisasi atau perusahaan seringkali menjadi isu yang sangat penting. Karena pentingnya hal tersebut, beberapa organisasi memasukkan unsur komitmen sebagai salah satu syarat untuk memegang suatu jabatan atau posisi yang ditawarkan dalam iklan-iklan lowongan pekerjaan [6].

Komitmen kerja secara umum dapat diartikan sebagai keterikatan karyawan pada organisasi dimana karyawan tersebut bekerja. Komitmen dibutuhkan oleh organisasi agar sumber daya manusia yang kompeten dalam organisasi dapat terjaga dan terpelihara dengan baik. Perusahaan selalu menginginkan pencapaian tujuan tanpa banyak mengalami kendala, diantaranya tujuan mencapai laba, memenangkan persaingan, memenuhi kepuasan pelanggan dan lain-lain. Namun permasalahan pencapaian tujuan ini tidak sesederhana yang dipikirkan pihak manajemen. Kendala-kendala utama yang dapat timbul terutama dapat berasal dari para karyawan sebagai anggota organisasi, seperti rendahnya komitmen karyawan untuk tetap bekerja dalam jangka waktu yang ditentukan oleh perusahaan.

Beberapa alasan mengapa organisasi harus melakukan berbagai usaha untuk meningkatkan derajat komitmen kerja dalam diri karyawan. Pertama, semakin tinggi komitmen kerja karyawan semakin tinggi pula usaha yang dikeluarkan karyawan dalam mengerjakan pekerjaannya. Kedua, semakin tinggi komitmen karyawan semakin lama ia ingin tetap berada dalam organisasi dan semakin tinggi pula produktivitasnya. Karyawan yang komitmen kerjanya tinggi, maka hal ini dapat mendukung pencapaian tujuan perusahaan.

Hasil pengamatan awal dilapangan ditemukan masih ada pengurus BKM yang perlu dipertanyakan komitmen kerjanya, hal ini dikarenakan kurang aktifnya mereka disetiap kegiatan-kegiatan BKM. Hal ini berpengaruh besar terhadap kinerja BKM, karena segala keputusan yang dihasilkan dan akan dikerjakan harus melalui rapat dan peran aktif semua pengurus. Jikalau pengurus BKM komitmennya rendah terhadap organisasi, maka bisa dipastikan semua kegiatan dan kesepakatan akan tersendat-sendat, kurang aspiratif serta memicu penurunan kinerja BKM. Begitupun sebaliknya jika komitmen kerjanya tinggi maka segala kegiatan dan kesepakatan bisa dihasilkan dengan baik serta akan 
meningkatkan kinerja BKM. Berdasarkan peninjauan lapangan mengenai pelaksanaan kegiatan Badan Keswadayaan Masyarakat ditemukan beberapa pokok permasalahan terutama mengenai penerapan knowledge management dan komitmen kerja dalam pelaksanaannya disinyalir masih ada Pengurus BKM yang dalam menjalankan program kurang memahami arti penting dari Kinerja Pengurus Badan Keswadayaan Masyarakat tersebut sehingga target indikator penilaian BKM yang dilaksanakan tidak tercapai. Dengan demikian, penelitian ini bertujuan untukmenguji dan menjelaskan pengaruh knowledge management dan komitmen kerja terhadap kinerja Pengurus Badan Keswadayaan Masyarakat (BKM) Kota Kendari.

\section{METODE PENELITIAN}

Penelitian ini adalah penelitian survei, dengan mengambil sampel dari populasi dengan menggunakan daftar pernyataan sebagai alat pengumpulan data. Penelitian survey merupakan penyelidikan yang dilakukan untuk memperoleh fakta-fakta mengenai fenomena-fenomena yang ada dalam masyarakat untuk mencari keterangan yang lebih faktual dan sistematis. Selain itu dalam penelitian survei selain mengandalkan daftar pernyataan sebagai instrumen pengumpulan data juga dapat dilakukan dengan dengan wawancara dan studi dokumen. Survey dalam penelitian ini dilakukan dengan mengambil sampel dari pengurus Badan Keswadayaan masyarakat (BKM) di Kota Kendari dan menggunakan kuesioner sebagai alat pengumpulan data yang utama.

Metode penelitian yang digunakan dalam penelitian ini adalah explanatory research yaitu bertujuan untuk mengetahui pengaruh penyusunan dari suatu dimensi kehidupan [7]. Penelitian ini bertujuan untuk membuktikan bahwa adanya pengaruh variabel bebas yaitu knowledge management, komitmen kerja, dan kinerja BKM.

Penelitian ini di laksanakan pada 64 BKM yang tersebar di seluruh Kota kendari, dimana setiap kelurahan terdapat Badan Keswadayaan Masyarakat (BKM) dengan pertimbangan bahwa tingkat keberhasilan program tersebut berkaitan erat dengan knowledge management, komitmen kerja, dan kinerja BKM. Jumlah populasi yang dijadikan responden dalam penelitian ini berjumlah 666 orang, maka peneliti menggunakan teknik penarikan sampel secara Probability Sampling dengan menggunakan Metode Slovin [8], yang mana batas Kesalahan Toleransi sebesar 10\%, sehingga total sampel penelitian berjumlah 87 responden. 
Pengujian instrumen dilakukan dengan tujuan untuk menguji apakah instrumen yang digunakan dalam penelitian ini memenuhi syarat-syarat alat ukur yang baik atau sesuai dengan standar metode penelitian. Mengingat pengumpulan data dalam penelitian ini menggunakan kuesioner, maka keseriusan atau kesungguhan responden dalam menjawab pertanyaan-pertanyaan merupakan unsur penting dalam penelitian. Keabsahan atau kesahihan data hasil penelitian sosial sangat ditentukan oleh instrumen yang digunakan.Instrumen dikatakan baik apabila memenuhi tiga persyaratan utama yaitu: (1) valid atau sahih; (2) reliabel atau andal; dan (3) praktis [9]. Bilamana alat ukur yang digunakan tidak valid atau tidak dapat dipercaya dan tidak andal atau reliabel, maka hasil penelitian tidak akan menggambarkan keadaan yang sesuangguhnya. Oleh karena itu, untuk menguji kuesioner sebagai instrumen penelitian maka digunakan uji validitas (test of validity) dan uji reliabilitas (test of reliability) [10].

Metode analisis data yang digunakan dalam penelitian ini yaitu regresi linier bergandadengan menggunakan sofware SPSS versi 21.0.Analisis deskripsibertujuan untuk menginterprestasikan mengenai argumen responden terhadap pilihan pernyataan dan distribusi frekuensi pernyataan responden dari data yang telah dikumpulkan. Dalam penelitian ini jawaban responden dikategorikan dalam lima kategori dengan menggunakan skala Likert. Masing-masing skala mempunyai gradasi penilaian dari sangat rendah ke sangat tinggi yang dituangkan dalam pilihan jawaban kuesioner. Kemudian mendeskriptifkan masing-masing variabel penelitian, karakteristik responden maupun gambaran umum obyek penelitian dalam bentuk alasan terhadap pernyataan responden, jumlah, rata-rata, dan persentase.

Analisis regresi linier bergandadalam penelitian ini bertujuan untuk menguji dan menjelaskan pengaruh masing-masing variabel penelitian ini. Alasan penggunaan analisis regresi multivariat karena: (1) input data dalam pengolahan merupakan hasil perhitungan rata-rata dari setiap item pernyataan atau indikator variabel; (2). penelitian ini pengukurannya dengan menggunakan skala sikap atau tanggapan responden oleh karena itu hasil estimasi perlu distandardized, (3) Analisis regresi linier berganda; (4) model yang terbentuk pada kerangka konseptual penelitian ini, terlihat ada pengaruh yaitu knowledge management dan komitmen kerja berpengaruh terhadap kinerja, knowledge management berpengaruh terhadap kinerja, komitmen kerja berpengaruh terhadap kinerja. 


\section{HASIL DAN PEMBAHASAN}

\section{a. Deskripsi Variabel Penelitian}

\section{1) Deskripsi Variabel Knowledge Management $\left(X_{1}\right)$}

Knowledge managementakan terungkap melalui jawaban responden terhadap pernyataan-pernyataan yang diajukan pada kuesioner. Knowledge management diukur menggunakan 4 Indikator dan dioperasionalisasikan menjadi 12 butir pernyataan dimana terbagi 3 butir pada sosialisasi, 3 butir padaExternalisasi, 3 butir pada Kombinasi, 3 butir pada Internalisasi. Berikut hasil kategorisasi rata-rata skortanggapan responden terhadap masing-masing butir pernyataan pada variabel knowledge management.

Tabel 2.Frekuensi Jawaban Responden atasVariabel Knowledge Management $\left(\mathrm{X}_{1}\right)$

\begin{tabular}{|c|c|c|c|c|c|c|}
\hline Variabel & Indikator & $\begin{array}{l}\text { Item } \\
\text { (Butir) }\end{array}$ & $\begin{array}{c}\text { Koefisien } \\
\text { korelasi }\end{array}$ & Ket & $\begin{array}{c}\text { Cronbach } \\
\text { Alpha }\end{array}$ & Ket \\
\hline \multirow{12}{*}{$\begin{array}{l}\text { Knowledge } \\
\text { Manajemen }\left(\mathrm{X}_{1}\right)\end{array}$} & \multirow{3}{*}{ Sosialisasi $\left(\mathrm{X}_{1.1}\right)$} & $X_{1.1 .1}$ & 0,439 & Valid & \multirow{12}{*}{0,781} & \multirow{12}{*}{ Reliabel } \\
\hline & & $\mathrm{X}_{1.1 .2}$ & 0,563 & Valid & & \\
\hline & & $\mathrm{X}_{1.1 .3}$ & 0,534 & Valid & & \\
\hline & \multirow{3}{*}{$\begin{array}{l}\text { Externalisasi } \\
\qquad\left(\mathrm{X}_{1.2}\right)\end{array}$} & $\mathrm{X}_{1.2 .1}$ & 0,430 & Valid & & \\
\hline & & $\mathrm{X}_{1.2 .2}$ & 0,552 & Valid & & \\
\hline & & $\mathrm{X}_{1.2 .2}$ & 0,60 & Valid & & \\
\hline & \multirow{3}{*}{ Kombinasi $\left(\mathrm{X}_{1.3}\right)$} & $X_{1.3 .1}$ & 0,630 & Valid & & \\
\hline & & $\mathrm{X}_{1.3 .2}$ & 0,568 & Valid & & \\
\hline & & $\mathrm{X}_{1.3 .3}$ & 0,667 & Valid & & \\
\hline & \multirow{3}{*}{$\begin{array}{l}\text { Internalisasi } \\
\quad\left(\mathrm{X}_{1.4}\right)\end{array}$} & $\mathrm{X}_{1.4 .1}$ & 0,547 & Valid & & \\
\hline & & $\mathrm{X}_{1.4 .2}$ & 0,607 & Valid & & \\
\hline & & $\mathrm{X}_{1.4 .3}$ & 0,558 & Valid & & \\
\hline
\end{tabular}

Sumber: Data Primer (diolah), 2014

Tabel 2 menunjukan bahwa dalam penelitian ini variabel knowledge management (X1) yang terdiri dari 4 indikator dimana terdapat 12 butir pernyataan dengan pembagian 4 indikator dan dioperasionalisasikan menjadi 12 butir pernyataan dimana terbagi 3 butir pada sosialisasi, 3 butir pada eksternalisasi, 3 butir pada kombinasi, 3 butir pada internalisasi. diperoleh nilai rata-rata jawaban responden dari keempat indikator tersebut adalah 3,9. Berdasarkan nilai interval penskoran jawaban, angka 3,9 berada pada interval $(2,62-3,40)$ yang diinterpretasikan bahwa jawaban responden tersebut adalah tergolong Tinggi/Baik. Hal ini menggambarkan bahwa knowledge management tergolong baik. 


\section{2) Deskripsi Variabel Komitmen Kerja $\left(\mathbf{X}_{2}\right)$}

Komitmen kerjaterungkap melalui jawaban responden terhadap pernyataan-pernyataan yang diajukan pada kuesioner. Komitmen kerjadiukur menggunakan 3 indikator dan dioperasionalisasikan menjadi 9 butir pernyataan. Berikut hasil kategorisasi rata-rata skor tanggapan responden terhadap masing-masing butir pernyataan pada variable gaya kepemimpinan transformasional.

Tabel 3.Frekuensi Jawaban Responden atas Variabel Komitmen Kerja $\left(\mathbf{X}_{2}\right)$

\begin{tabular}{|c|c|c|c|c|c|c|}
\hline Variabel & Indikator & $\begin{array}{l}\text { Item } \\
\text { (Butir) }\end{array}$ & $\begin{array}{c}\text { Koefisien } \\
\text { korelasi }\end{array}$ & Ket & $\begin{array}{c}\text { Cronbach } \\
\text { Alpha }\end{array}$ & Ket \\
\hline \multirow{9}{*}{$\begin{array}{l}\text { Komitmen Kerja } \\
\left(\mathrm{X}_{2}\right)\end{array}$} & \multirow{3}{*}{$\begin{array}{c}\text { Affective } \\
\text { Commitment } \\
\left(\mathrm{X}_{2.1}\right)\end{array}$} & $\mathrm{X}_{2.1 .1}$ & 0,441 & Valid & \multirow{9}{*}{0,749} & \multirow{9}{*}{ Reliabel } \\
\hline & & $\mathrm{X}_{2.1 .2}$ & 0,417 & Valid & & \\
\hline & & $\mathrm{X}_{2.1 .3}$ & 0,629 & Valid & & \\
\hline & \multirow{3}{*}{$\begin{array}{c}\text { Normative } \\
\text { Commitment } \\
\left(\mathrm{X}_{2.2}\right)\end{array}$} & $\mathrm{X}_{2.2 .1}$ & 0,642 & Valid & & \\
\hline & & $\mathrm{X}_{2.2 .2}$ & 0,691 & Valid & & \\
\hline & & $\mathrm{X}_{2.2 .3}$ & 0,685 & Valid & & \\
\hline & \multirow{3}{*}{$\begin{array}{c}\text { Contiuance } \\
\text { Commitment } \\
\left(\mathrm{X}_{2.3}\right)\end{array}$} & $\mathrm{X}_{2.3 .1}$ & 0,781 & Valid & & \\
\hline & & $\mathrm{X}_{2.3 .2}$ & 0,650 & Valid & & \\
\hline & & $\mathrm{X}_{2.3 .3}$ & 0,497 & Valid & & \\
\hline
\end{tabular}

Sumber : Data Primer (diolah), 2014

Tabel3menunjukkan bahwa variabel Komitmen Kerja (X2) yang terdiri dari 3 (tiga) indikator diperoleh nilai rata-rata jawaban responden adalah sebesar 4,33. Berdasarkan nilai interval penskoran jawaban, angka 4,33 berada pada interval $(4,22$ $5,00)$ yang diinterpretasikan bahwa jawaban responden tersebut adalah tergolong sangat tinggi/ sangat baik. Hal ini menggambarkan bahwa komitmen kerja.

\section{3) Deskripsi Variabel Kinerja Organisasi (Y)}

Kinerja organisasi diukur menggunakan 4 indikator dan dioperasionalisasikan menjadi 4 butir pernyataan. Berikut hasil kategorisasi rata-rata skor tanggapan responden terhadap masing-masing butir pernyataan pada variabel disiplin karyawan.

Tabel 4. Frekuensi Jawaban Responden ata Variabel Kinerja Organisasi (Y)

\begin{tabular}{|c|c|c|c|c|c|c|}
\hline Variabel & Indikator & $\begin{array}{l}\text { Item } \\
\text { (Butir) }\end{array}$ & $\begin{array}{c}\text { Koefisien } \\
\text { korelasi }\end{array}$ & Ket & $\begin{array}{c}\text { Cronbach } \\
\text { Alpha }\end{array}$ & Ket \\
\hline \multirow{7}{*}{ Kinerja (Y) } & \multirow{4}{*}{ Quality } & $\mathrm{Y}_{1.1}$ & 0,418 & Valid & \multirow{7}{*}{0,721} & \multirow{7}{*}{ Reliabel } \\
\hline & & $\mathrm{Y}_{1.2}$ & 0,484 & Valid & & \\
\hline & & $Y_{1.3}$ & 0,332 & Valid & & \\
\hline & & $\mathrm{Y}_{1.4}$ & 0,440 & Valid & & \\
\hline & \multirow{3}{*}{ Quantity } & $\mathrm{Y}_{2.1}$ & 0,585 & Valid & & \\
\hline & & $\mathrm{Y}_{2.2}$ & 0,580 & Valid & & \\
\hline & & $\mathrm{Y}_{2.3}$ & 0,487 & Valid & & \\
\hline
\end{tabular}




\begin{tabular}{|c|c|c|c|}
\hline \multirow{3}{*}{ Timelines } & $\mathrm{Y}_{3.1}$ & 0.487 & Valid \\
\hline & $\mathrm{Y}_{3.2}$ & 0.406 & Valid \\
\hline & $\mathrm{Y}_{3.3}$ & 0.401 & Valid \\
\hline \multirow{3}{*}{$\begin{array}{c}\text { Need } \\
\text { Supervision }\end{array}$} & $\mathrm{Y}_{4.1}$ & 0,386 & Valid \\
\hline & $\mathrm{Y}_{4.2}$ & 0,511 & Valid \\
\hline & $\mathrm{Y}_{4.3}$ & 0,525 & Valid \\
\hline \multirow{4}{*}{$\begin{array}{l}\text { Interpersonal } \\
\text { Impact }\end{array}$} & $\mathrm{Y}_{5.1}$ & 0,517 & Valid \\
\hline & $\mathrm{Y}_{5.2}$ & 0,528 & Valid \\
\hline & $\mathrm{Y}_{5.3}$ & 0,494 & Valid \\
\hline & $\mathrm{Y}_{5.4}$ & 0,476 & Valid \\
\hline
\end{tabular}

Sumber: Data Primer (diolah), 2014

Tabel 4menunjukan bahwa variabel Disiplin Karyawan $(Y)$ yang terdiri dari 5 (lima) indikator diperoleh nilai rata-rata jawaban responden dari kelima indikator tersebut adalah sebesar 3,86. Berdasarkan nilai interval penskoran jawaban, angka 3,86 berada pada interval $(3,41-4,21)$ yang diinterprestasikan bahwa jawaban responden tersebut adalah tergolong tinggi/baik.

\section{b. Hasil Pengolahan Data}

Salah satu syarat yang harus dipenuhi dalam analisis regresi adalah data dan model regresi berdistribusi normal. Kenormalan data dapat dilihat dari uji normalitas Kolmogorov-Smirnof dari masing-masing variabel [10].

Tabel 5. One-Sample Kolmogorov-Smirnov Test

\begin{tabular}{|ll|r|r|r|}
\hline & & \multicolumn{1}{|c|}{$\begin{array}{c}\text { Knowledge } \\
\text { Management }\end{array}$} & Komitmen Kerja & \multicolumn{1}{c|}{$\begin{array}{c}\text { Kinerja } \\
\text { Organisasi }\end{array}$} \\
\hline $\mathrm{N}$ & & 87 & 87 & 87 \\
Normal Parameters & Mean & 46.83 & 38.99 & 66.23 \\
& Std. Deviation & 5.307 & 2.911 & 7.044 \\
& Absolute & .099 & .089 & .075 \\
Most Extreme Differences & Positive & .071 & .066 & .075 \\
& Negative & -.099 & -.089 & -.070 \\
Kolmogorov-Smirnov Z & & .925 & .826 & .700 \\
Asymp. Sig. (2-tailed) & & .359 & .503 & .711 \\
\hline
\end{tabular}

a. Test distribution is Normal.

b. Calculated from data.

Hasil Uji Normalitas Menggunakan Kolmogorov Smirnov terlihat Sig untuk dua sisi diperoleh nilai signifikansi variabel knowledge management sebesar 0,359 untuk variabel komitmen kerja sebesar 0,503 dan variabel kenerja pengurus BKM sebesar 0,711. Nilai signifikansi dari masing-masing variabel > 0,05 yang berarti bahwa Ho diterima atau data dari masing-masing variabel berdistribusi normal. Dengan demikian berdasarkan hasil uji normalitas di atas menunjukan bahwa ketiga variabel dalam 
penelitian ini baik knowledge management $\left(\mathrm{X}_{1}\right)$, variabel komitmen kerja $\left(\mathrm{X}_{2}\right)$ maupun variabel kinerja pengurus BKM (Y) memiliki distribusi data yang normal. Dengan demikian dapat dikatakan bahwa data dalam penelitian ini dapat mewakili populasi sehingga hasil analisis dan kesimpulan data dalam penelitian dapat digeneralisasikan terhadap populasi penelitian.

\section{c. Pengujian Hipotesis}

$\mathrm{H}_{1}$ : Pengaruh Antara knowledge managementdengankomitmen kerjaterhadap kinerja pengurusBadan Keswadayaan Masyarakat (BKM) Kota Kendari.

Pengujian hipotesis pertama knowledge management dan komitmen kerja berpengaruh positif dan signifikan terhadap kinerja Pengurus Badan Keswadayaan Masyarakat (BKM) Kota Kendari dengan nilai 3,114 dengan tingkat signifikansi sebesar 0.023 Ini menunjukkan bahwa pengaruh knowledge management secara parsial berpengaruh positif dan signifikan terhadap variabel kinerja pengurus Badan Keswadayaan Masyarakat (BKM) Kota Kendari.

$\mathrm{H}_{2}$ : Terdapat pengaruh positif dan signifikan komitmen kerja terhadap kinerja pengurus Badan Keswadayaan Masyarakat (BKM) Kota Kendari.

Berdasarkan hasil analisis menunjukkan bahwa nilai thitung variabel komitmen kerjasebesar 3,187 dengan tingkat signifikansi sebesar 0.002. Ini menunjukkan bahwa pengaruh komitmen kerjasecara parsial berpengaruh positif dan signifikan terhadap variabel kinerja pengurus Badan Keswadayaan Masyarakat (BKM) Kota Kendari.

$\mathrm{H}_{3}$ : Terdapat pengaruh positif dan signifikan knowledge management terhadap kinerja pengurus Badan Keswadayaan Masyarakat (BKM).

Berdasarkan hasil analisis, menunjukkan bahwa nilai thitung variabel knowledge management sebesar 3,114 dengan tingkat signifikansi sebesar 0.023. Ini menunjukkan bahwa pengaruh knowledge management secara parsial berpengaruh positif dan signifikan terhadap variabel kinerja pengurus Badan Keswadayaan Masyarakat (BKM) Kota Kendari.

\section{d. Pembahasan}

1) Pengaruh Knowledge Management dan Komitmen Kerja terhadap Kinerja Pengurus BKM 
Hasil perhitungan ketiga variabel pada penelitian ini menunjukan bahwa terdapat pengaruh positif dan signifikan knowledge management dan komitmen kerja secara bersama-sama terhadap kinerja pengurus BKM. Kontribusi besarnya hubungan secara bersama-sama antara knowledge management dan komitmen kerja dengan kinerja pengurus BKM. sehingga dapat disimpulkan bahwa terdapat pengaruh positif dan signifikan knowledge management dan komitmen kerja terhadap kinerja pengurus BKM se Kota Kendari. Sedangkan kontribusi variabel knowledge management dan komitmen kerja terhadap kinerja pengurus BKM dijelaskan oleh variabel knowledge management dan komitmen kerja sedangkan sisanya dijelaskan oleh variabel lain yang tidak diteliti.

Interpretasi diatas menjelaskan bahwa meningkatnya kinerja pengurus BKM tidak terlepas dari tinggi rendahnya knowledge management pengurus BKM dan komitmen kerja pengurus BKM itu sendiri. Semakin tinggi nilai knowledge management dan komitmen kerja maka akan semakin tinggi pula kinerja pengurus BKM, begitupun sebaliknya bila semakin rendah nilai knowledge management dan komitmen kerja pengurus maka semakin rendah pula kinerja pengurus BKM sehingga perlunya pengurus BKM selalu mengevaluasi seluruh aspek yang menyangkut kinerja agar kestabilan kinerja minimal dapat dipertahankan dan ditingkatkan disetiap kesempatan.

\section{2) Pengaruh Knowledge Management terhadap Kinerja Pengurus BKM}

Setelah dilakukan analisis data yang diperoleh serta melakukan uji hipotesis, maka berikut ini penulis akan menguraikan dalam bentuk pembahasan hasil penelitian. Berdasarkan hasil olahan data dari jawaban responden pengurus BKM Kota Kendari menunjukan bahwa penerapan knowledge management sudah dilaksanakan sehingga mengakibatkan kinerja pengurus BKM se kota Kendari menjadi kondusif.Hasil analisis hipotesis menunjukan bahwa ada pengaruh positif dan signifikan antara knowledge managemet terhadap kinerja pengurus BKM. Hal ini menunjukan bahwa tinggi rendahnya kinerja pengurus BKM dipengaruhi oleh knowledge managemet. Semakin baik knowledge management yang diterapkan pada BKM maka semakin tinggi kinerja pengurus BKM.

Komponen sosialisasi sangat berpengaruh terhadap peningkatan kinerja pengurus BKM, dimana pada komponen ini adalah perwujudan tacit ke tacit atau dari ide ke ide sehingga ide dan gagasan yang disampaikan secara terus menerus baik dari 
individu ke individu maupun dari individu ke kelompok akan membuat tujuan dari organisasi tetap terpelihara. Begitupun sebaliknya, bila ide dan gagasan dari organisasi tidak tersosialisasikan dengan baik niscaya akan mengganggu tujuan organisasi itu sendiri.

\section{3) Pengaruh Komitmen Kerja terhadap Kinerja Pengurus BKM}

Hasil pengujian regresi mengenai pengaruh antara variabel komitmen kerja $\left(\mathrm{X}_{2}\right)$ dengan variabel kinerja pengurus BKM (Y) maka disimpulkan bahwa pengaruh kedua variabel adalah positif, Hal ini menunjukkan bahwa tinggi rendahnya kinerja pengurus BKM dipengaruhi oleh komitmen kerja yang diterapkan pada BKM Kota Kendari. Semakin baik komitmen kerja yang diterapkan oleh BKM Kota Kendari, maka akan semakin tinggi kinerja pengurus BKM.Komponen-komponen yang melekat pada komitmen kerja sangat berpengaruh terhadap kinerja pengurus dimana komitmen kerja pengurus sangat dibutuhkan dalam meraih kesuksesan sebuah organisasi.

\section{KESIMPULAN}

Berdasarkan hasil penelitian dan pembahasan mengenai pengaruh knowledge management dan komitmen kerja terhadap kinerja Pengurus Badan Keswadayaan Masyarakat (BKM) di Kota Kendari dapat ditarik kesimpulan sebagai berikut.

Knowledge management berpengaruh terhadap kinerja pengurus BKM. Hal ini menunjukkan bahwa tinggi rendahnya kinerja pengurus BKM dipengaruhi oleh knowledge management yang diterapkan pengurus BKM se Kota Kendari. Semakin baik knowledge management yang diterapkan oleh BKM, maka akan semakin tinggi kinerja pengurus.

Komitmen kerja berpengaruh terhadap kinerja pengurus BKM. Hal ini menunjukkan bahwa tinggi rendahnya kinerja pengurus BKM dipenaruhi oleh komitmen kerja yang diterapkan pada BKM Kota Kendari. Semakin baik komitmen kerja yang diterapkan oleh BKM Kota Kendari, maka akan semakin tinggi kinerja pengurus BKM.

Knowledge management dan Komitmen kerja secara bersama-sama berpengaruh terhadap kinerja pengurus BKM.Hal ini menunjukan bahwa knowledge management dan komitmen kerja memiliki korelasi positif terhadap keberhasilan pengurus BKM dalam melakukan pekerjaannya. 


\section{SARAN}

Dari berbagai permasalahan, hambatan, kendala dan kelemahan dalam upaya peningkatan kinerja BKM di Kota Kendari maka dalam rangka perbaikan kedepan beberapa saran dapat dikemukakan sebagai berikut.

Penelitian mengenai Knowledge Management pada BKM se Kota Kendari masih relatif terbatas, sedangkan dampaknya terhadap kinerja pengurus sangat besar. Salah satu upaya mencari pemecahan masalah yang terkait dengan peningkatan kinerja pengurus pada BKM se Kota Kendari perlu dilakukan penelitian serupa dalam cakupan yang lebih luas, baik dalam lingkup disiplin ilmu yang sama maupun antar disiplin ilmu dengan cara mengembangkan teori knowledge management. Kompleksitas faktor-faktor yang mempengaruhi kinerja pengurus perlu dicermati secara terus menerus. Kemungkinan adanya faktor lain diluar variabel yang diteliti memberi peluang untuk dikaji kembali.

Komitmen kerja pada pengurus BKM perlu dikaji kembali dengan menambahkan berbagai variabel penunjang sehingga dapat terpolakan model komitmen kerja yang ideal karena dengan komitmen kerja yang tinggi dapat meningkatkan kinerja pengurus BKM secara umum.

Pengurus BKM perlu melakukan evaluasi secara periodik terhadap knowledge management dan komitmen kerja pengurus guna menjaga suasana organisasi yang kondusif serta dapat menemukenali variabel yang dapat mengganggu kinerja pengurus BKM baik secara langsung maupun tidak langsung.

\section{DAFTAR PUSTAKA}

[1] Sumaryadi, I Nyoman. 2005.Perencanaan Pembangunan Daerah Otonom dan Pemberdayaan Masyarakat. Jakarta : Citra Utama.

[2] Davenport, Thomas H dan Prusak, Laurence. 2000. Working Knowledge: How Organizations Manage What They Know. Boston: Harvard Bussiness School Press.

[3] Nonaka, I., and Takeuchi, H. 1995. The Knowledge Creating Company. New York: Oxford University Press.

[4] Setiadi, Nugroho J. 2003, Perilaku Konsumen. Kencana. Jakarta.

[5] Mardiana, T. (2004). Pengaruh karakteristik individu, karakteristik pekerjaan dan pengalaman kerja terhadap komitmen organisasi (studi empiris pada rumah sakit panti rapih yogyakarta). Telaah Bisnis, 5 (2): 175-191.

[6] Kuntjoro, S. 2002. Manajemen Sumber Daya Manusia. CV. Rajawali Press; Jakarta.

[7] Salimun. 2002. Analisis Multivariat: Structural Equation Modelling. IKIP Malang; Malang. 
[8] Umar, Husein. 2008. Metodologi Penelitian Untuk Skripsi dan Tesis Bisnis. PT.Raya Grafindo Persada. Jakarta.

[9] Sekaran, Uma. 2011. Research Methods for Business: A Skill-Building Approach. Forth Edition. Salemba Empat; Jakarta.

[10] Santoso, Singgih. 2014. Konsep Dasar dan Aplikasi SEM dengan AMOS 22. PT Elex Media Komputindo. Jakarta. 